\title{
Performance evaluation of $108 \mathrm{KW}$ grid connected solar photovoltaic System
}

\author{
Haidar Gafar Abugoukh \\ O.M. Beketov National University of Urban Economy in Kharkov \\ Ukraine \\ E-mail: haidarjokh2004@yahoo.com
}

\begin{abstract}
Annotation - Solar power has emerged as the fastest growing energy generation technology globally over the past decade, mainly due to large scale adoption of the technology by utilities and private sector. Increasing awareness of climate changes, energy security needs facilitation from government decline in solar energy costs and emergence of new and innovative business are some of the prime drivers for the large scale development and deployment of the solar energy. Importance of Solar energy Solar energy is an important part of life and has been since the beginning of time. Increasingly, man is learning how to harness this important resource and use it to replace traditional energy sources. Solar Energy Is Important in Nature: Solar energy is an important part of almost every life process, if not, all life processes. Solar Energy Is Important as Clean Energy: Since solar energy is completely natural, it is considered a clean energy source. It does not disrupt the environment or create a threat to Eco-systems the way oil and some other energy sources might. It does not cause greenhouse gases, air or water pollution. This study aims to design and evaluate the grid-connected solar photovoltaic roof-top system. A design and feasibility study of rooftop solar photovoltaic system project is conducted using tools- PVsyst, The performance of the system was simulated using PVsyst software and the results were analyzed. The analyses of the simulation results show that the Maximum total energy generation of $\mathbf{1 8 . 2 3}$ MW $h$ was observed in the month of May and lowest total energy generation of $10.10 \mathrm{MWh}$ was observed in the month of December. The utilization of roof building will be increasing the amount of solar energy injected into grid. The utilization of roof building will be increasing the amount of solar energy and achieving Dubai clean energy strategy 2050 goals which aims to provide seven per cent of Dubai's power through clean energy by 2020, 25 per cent by 2030 and 75 per cent by 2050.
\end{abstract} ratio.

Keywords - Grid system, Photovoltaic (PV); Performance

\section{INTRODUCTION}

Nowadays, renewable energy resources play an important role in replacing conventional fossil fuel energy resources. Photovoltaic energy is one of the very promising renewable energy resources which grew rapidly in the past few years.

Renewable energy resources play an important role in electric power generation. There are various renewable resources which is used for electric power generation, such as solar energy, wind energy, geothermal etc. Solar Energy is a good choice for electric power generation, since the solar energy is directly converted into electrical energy by solar photovoltaic modules. These modules are made up of silicon cells. When many such cells are connected in series we get a solar PV module. The current rating of the modules increases when the area of the individual cells is increased, and vice versa. When many PV modules are connected in series and parallel combinations we get a solar PV array, which is suitable for obtaining higher power output.

The electricity consumption in the United Arab Emirates (UAE) has increased by $12 \%$ per annum from about $60,000 \mathrm{GWh}$ in 2006 to $85,000 \mathrm{GWh}$ in 2010 . the electricity peak demand in Dubai is increase from $3.228 \mathrm{MW}$ in 2004 to $8,507 \mathrm{MW}$ in 2018 . To meet this increasing energy demand, the Dubai relies heavily on gas and oil. As a matter of fact, $73 \%$ of the generation capacity is based on gas turbine generators $(7,448 \mathrm{MW})$, and $25 \%$ is based on steam turbine generators $(2,542 \mathrm{MW})$. As a result, the Dubai has a high ecological footprint per capita, and it actually had the world's highest in 2018 (figure 1). The government of Dubai has recently committed to have (1000MW) $1 \%$ of its generation capacity from renewable resources and mainly from solar energy by the year 2020 and $5000 \mathrm{MW}$ by 2030 .

The Mohammed bin Rashid Al Maktoum Solar Park is the largest single-site solar park in the world, with a planned capacity of $1,000 \mathrm{MW}$ by 2020 , and $5,000 \mathrm{MW}$ by 2030 , the solar park will use a range of photovoltaic and concentrated solar power technologies to provide clean energy to the citizens and residents of Dubai.

\section{- .SOlar Power In THE UAE}

The UAE (United Arab Emirates) is in the 'sunbelt region' in which solar irradiation levels (the amount of solar radiation which falls on the Earth) are very high. This means that a solar panel in the UAE can potentially produce double the electrical energy compared to a country with relatively lower irradiation levels such as Germany [5]. The UAE is also in a region where bad weather rarely affects solar power production, making it an ideal location for solar installations. Being in a region with nearly 365 days of sunlight a year, the UAE can easily become one of the largest producers of solar energy per capita.

The UAE is also part of a region rich in fossil fuels. Since the 1970s, the country underwent rapid economic growth powered by readily available oil and gas, and has attained high living standards with a per capita income amongst the highest in the world. However this also led to very high per capita energy consumption as cities grew and became very energy intensive. When the governments of the UAE and other GCC (Gulf Cooperation Council) countries realized that their conventional energy reserves 
were rapidly depleting they set out to make their economies less reliant on fossil fuel-based energy and more on renewable energy, helping the UAE to achieve energy security.

The development of large scale solar power installations as well as renewable energy goals for 2020 and 2030 also reflect the UAE's ambition to move forward.

\section{System Description}

The system description is given in table $\mathrm{kWp}$ rooftop system is chosen. The PV cell material chosen is monocrystalline because of the higher efficiency. The system is of fixed stand type and can sufficiently power a household of a small family.

\begin{tabular}{|c|c|c|c|c|c|}
\hline Electricity & & 2018 & 2018 & & الكهرباء ه \\
\hline Installed Capacity & MW' & 10,200 & 11,100 & ميجاوات & القدرة المركبة \\
\hline Gas Turbines & MW & 7,448 & 7,975 & ميجاوات & توربينات غازية \\
\hline Steam Turbines & MW & 2,542 & 2,715 & ميجاوات & توربينات بخارية \\
\hline Solar PV & $M W$ & 210 & 410 & ميجاوات & كهروضوئية شمية \\
\hline \multicolumn{6}{|l|}{ "MW - Megawatts } \\
\hline Peak Demand & MW & 8,232 & 8,507 & (ميجاوات) & الطلب الذروي \\
\hline
\end{tabular}

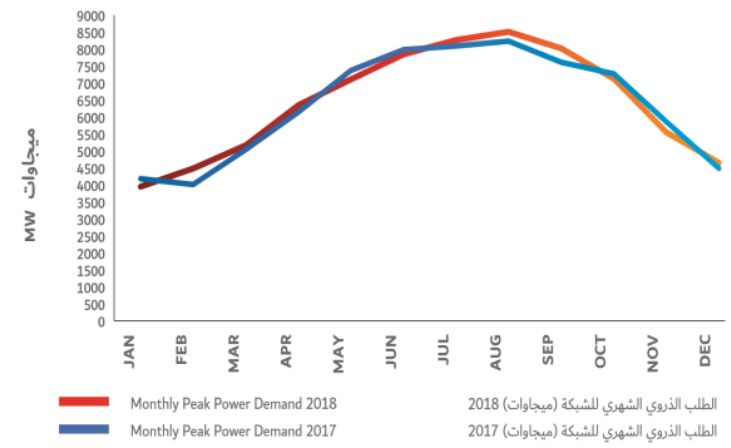

Fig. 1. Dubai Electricity and water authority (DEWA) statistics 2018

The grid connected PV system, consists of solar arrays to absorb and convert sunlight into electricity, a solar inverter to convert DC current to AC current, a mounting, cabling and other electrical accessories. Schematic of the grid connected PV system is shown in Fig. 2. The main component for grid-connected solar PV power systems comprise of:

Solar PV modules, connected in series and parallel, depending on the solar PV array size, to generate DC power directly from the sun's intercepted solar power. Maximum tracker (MPPT), making sure the solar PV modules generated DC power at their best power output at any given time during sunshine hours Grid-connected DC/AC inverter, making sure the generated and converted AC power is safely fed into the utility grid whenever the grid is available .Grid connection safety equipment like DC/AC breakers fuses etc., according to the local utility's rules and regulations

\section{DESCRIPTION OF THE SOLAR PV-GRID SYSTEM}

A grid -connected PV system consists of solar panels, inverters, a power conditioning and grid connection. It has effective utilization of power that is generated from solar energy as there are no energy storage losses. The grid connected PV system supplies the excess power, beyond consumption by the connected load to the utility grid through smart meters.

I. Geographical location of the site:

The solar plan located in Dubai at longitude of 55.28 E. Latitude $25.24 \mathrm{~N}$.

II. Specification of solar panel:

The solar panels mounted at the building are of $275 \mathrm{w}_{\mathrm{p}}$ rating and made up of polycrystalline. These panels have an efficiency of $16.8 \%$ and are of fixed type. Polycrystalline panel ratings are open circuit voltage (Voc) of $38.1 \mathrm{~V}$ and short circuit current (Isc) of $9.27 \mathrm{~A}$. It has a maximum operating temperature up to $+80^{\circ}$ centigrade.

- Creating a string of modules

A string comprises a number of PV modules connected in series. The electrical characteristics of PV modules connected in series to form a string are the same as PV cells connected in series to form a module: meaning the output voltage of the string will be the sum of the output voltages of all the modules and the output current of the string will be the lowest output current of any module.

Modules can also be connected in parallel. In this case the current output of the modules will add instead of the voltage. The output voltage is that of a single module.

The installation of the solar panel included is 3 inverters and 401 PV modules connected with 19 strings in parallel and 116 modules in series.

$>\quad$ Inverter \#1 (2X24, 2X24, 2X18, 1X15)

$>\quad$ Inverter \#2 (2X24, 2X22, 2X20)

$>\quad$ Inverter \#3 $(2 \mathrm{X} 17,2 \mathrm{X} 24,1 \mathrm{X} 18,1 \mathrm{X} 22)$

- Power conditioning units:

Inverter converts $\mathrm{DC}$ power into $\mathrm{AC}$ power. The inverter power rating is $36 \mathrm{~kW}$. PV voltage of $620 \mathrm{~V}$ and supply DC current $22 \mathrm{~A}$ is fed as input to inverter. The output AC voltage and current from inverter are $400 \mathrm{~V}$ and 57, 8 A respectively. The output of the inverter is synchronized automatically with same voltage and frequency as that of grid.

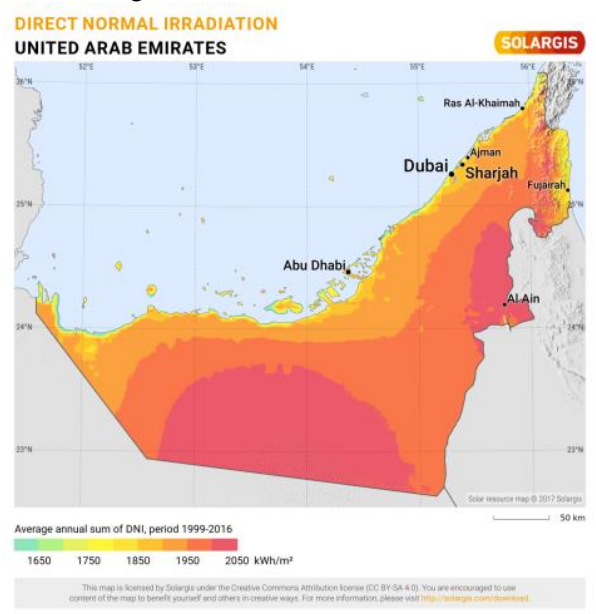

Fig. 2. Direct normal Irradiation in UAE 


\section{PV Output Modeling:-}

For the calculated utilizable roof area the energy production from the installed solar panels has been estimated with the help of PVsyst software employing the Dhahran weather conditions.

Specimen energy yield calculations for the academic buildings are provided in Figure 6 and Table 6.

Figure 7 specifically provides a detailed flow diagram of PV energy production from the buildings, while also highlighting the involved losses at various stages.

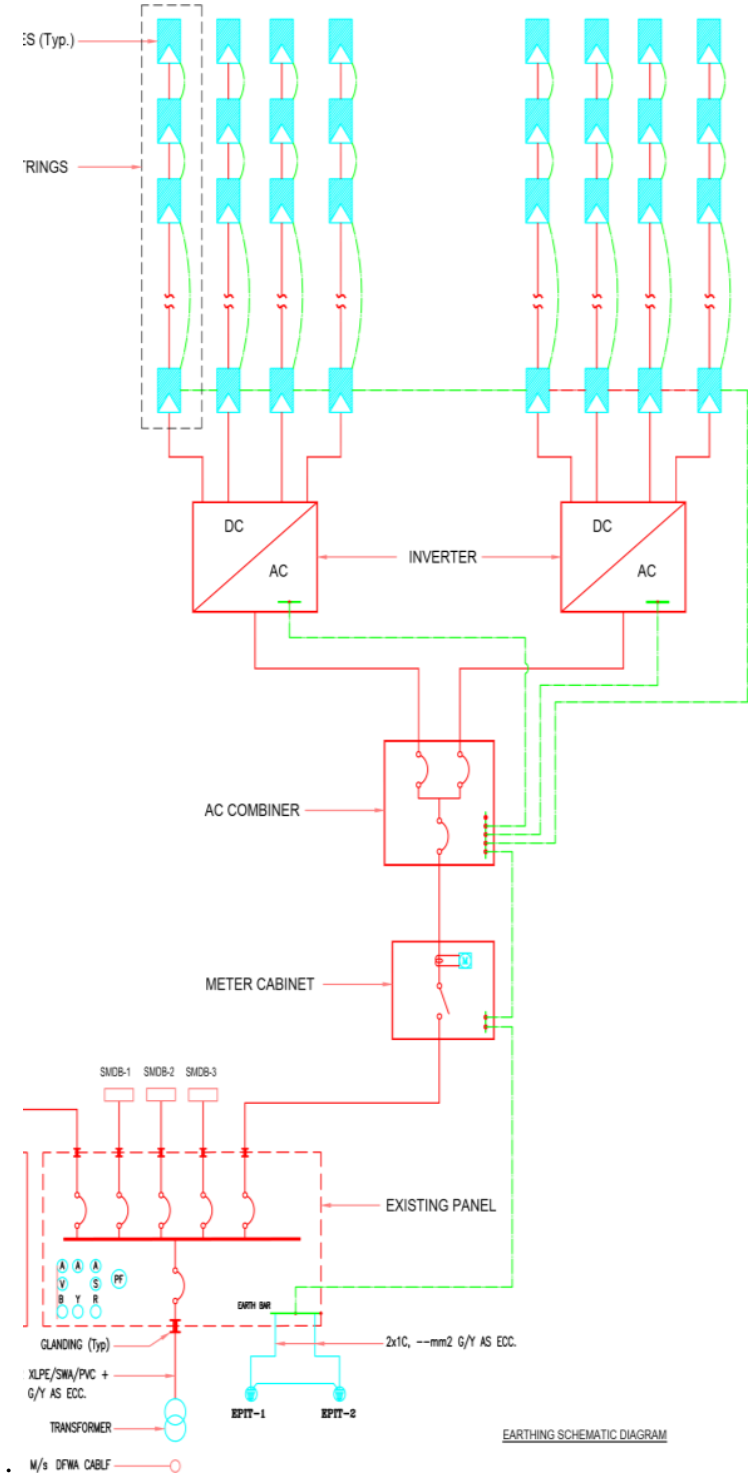

Fig. 3. Schematic layout of installed system.

\section{THE SIMULATION USING PV SYST}

The maximum energy is generated in the month of May (18.23MW h) and minimum energy is in the month of December $(10.10 \mathrm{MW} \mathrm{h})$. The total amount of energy injected into grid for the year 177.21 MW h.

Annual global horizontal irradiation is $2121,0 \mathrm{~kW}$ $\mathrm{h} / \mathrm{m} 2$. Global Incident energy that is incident on the collector plane annually is $2186.5 \mathrm{~kW} \mathrm{~h} / \mathrm{m}^{\wedge} 2$. Total energy obtained from the output of the PV array is $182,96 \mathrm{MW} \mathrm{h}$.

The annual average performance ratio is $73,5 \%$.

- Normalized productions:

The LC value is recorded as $1.44 \mathrm{kWh} / \mathrm{kW}$ p/day and the $\mathrm{LS}$ value is recorded as $0.14 \mathrm{~kW} \mathrm{h/kW}$ p/day in the same way $\mathrm{YF}$ is given as $4.4 \mathrm{~kW} \mathrm{h/kW} \mathrm{p/day.}$

TABLE I. OUTPUT RESULTS FOR THE BUILDINGS:-

\begin{tabular}{|l|l|l|}
\hline \multicolumn{1}{|c|}{ No } & \multicolumn{1}{|c|}{ System Parameter Output } & \multicolumn{1}{c|}{ QTY } \\
\hline 1 & Number of PV modules & 401 \\
\hline 2 & P nom. total .KWp & 110 \\
\hline 3 & Number of inverters & 3 \\
\hline 4 & Inverters Pnom total KW_AC & 108 \\
\hline 5 & Produced Energy MWh/year & 177.2 \\
\hline 6 & Specific production KWh/KWp/year & 1607 \\
\hline 7 & Performance ratio & $73.3 \%$ \\
\hline
\end{tabular}

TABLE II. SOLAR PANEL ELECTRICAL CHARACTERISTICS

\begin{tabular}{|l|l|}
\hline Rated Power (P max) & $275 \mathrm{~W}$ \\
\hline Voltage at P max (V mp) & $31.1 \mathrm{~V}$ \\
\hline Current at P max & $8.82 \mathrm{~A}$ \\
\hline Short Circuit Current (I sc) & $9.27 \mathrm{~A}$ \\
\hline Open Circuit Voltage (V oc) & $38.1 \mathrm{~V}$ \\
\hline
\end{tabular}

- Loss diagram:

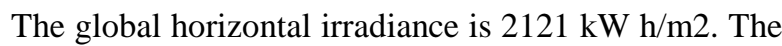
effective irradiation on the collector plane is $2007 \mathrm{~kW}$ $\mathrm{h} / \mathrm{m} 2$. Therefore, the loss in energy is $3.2 \%$. The solar energy incident on the solar panels will convert into electrical energy. After the PV conversion, the nominal array energy is $221,6 \mathrm{MWh}$. The efficiency of the PV array is $16.82 \%$ at standard test condition (STC). Array virtual energy obtained is $183,0 \mathrm{MW}$ h. After the inverter losses the available energy obtained at the inverter output is $177,2 \mathrm{MWh}$

\section{- $\mathrm{CO}_{2}$ emission reduction}

As the PV systems do not require fossil fuels to generate electricity, their life-cycle $\mathrm{CO}_{2}$ emissions are extremely low compared to electricity generated using conventional power plants. Therefore, the solar energy conversion using PV systems will result in a substantial reduction of $\mathrm{CO}_{2}$ 


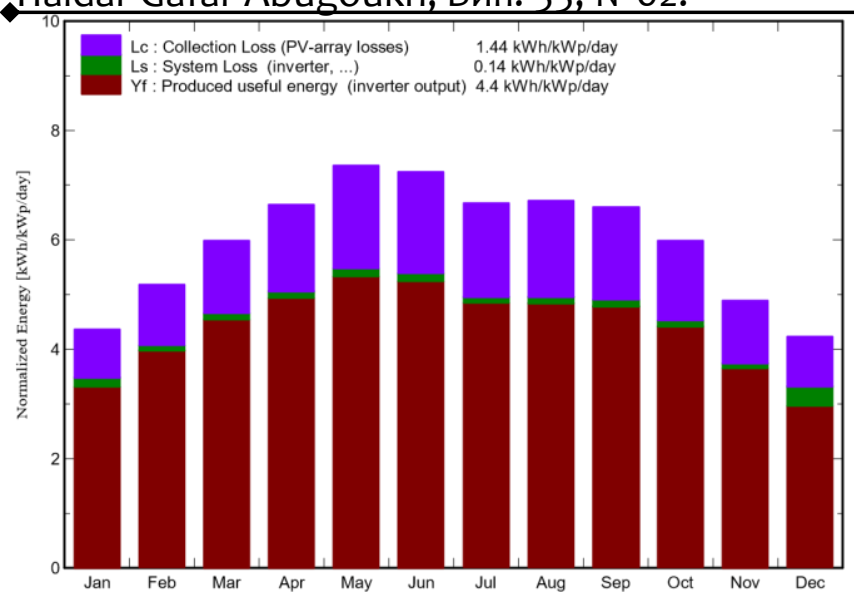

Fig. 4. Normalized Production for the building

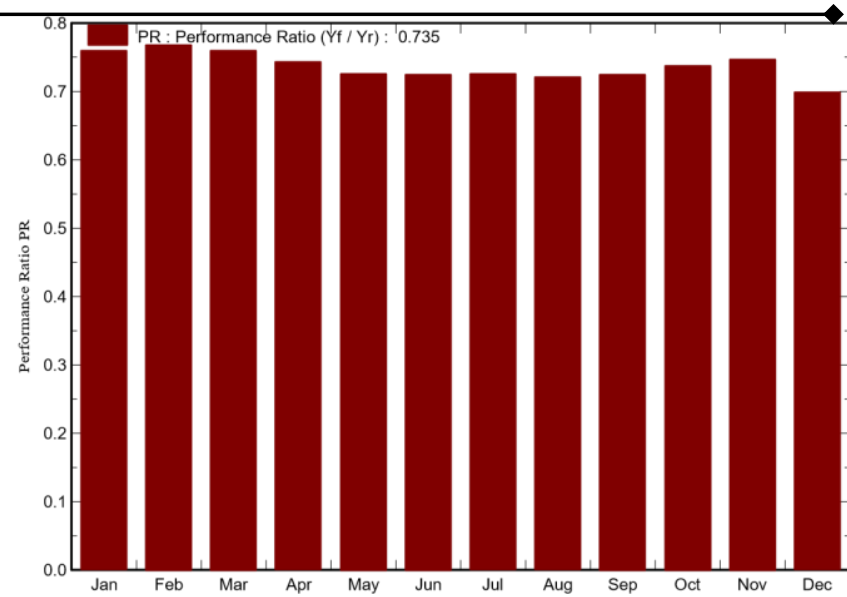

Fig. 5. Perfomance Ratio PR

TABLE III. BALANCES AND MAIN RESULTS

\begin{tabular}{|c|c|c|c|c|c|c|c|c|}
\hline & $\begin{array}{l}\text { GlobHor } \\
\mathbf{k W h} / \mathbf{m}^{2}\end{array}$ & $\begin{array}{l}\text { DiffHor } \\
\mathrm{kWh} / \mathrm{m}^{2}\end{array}$ & $\begin{array}{c}\text { T Amb } \\
{ }^{\circ} \mathbf{C}\end{array}$ & $\begin{array}{l}\text { GlobInc } \\
\mathbf{k W h} / \mathbf{m}^{2}\end{array}$ & $\begin{array}{l}\text { GlobEff } \\
\mathbf{k W h} / \mathrm{m}^{2}\end{array}$ & $\begin{array}{c}\text { EArray } \\
\text { MWh }\end{array}$ & $\begin{array}{c}\text { E_Grid } \\
\text { MWh }\end{array}$ & PR \\
\hline January & 123.8 & 48.4 & 19.70 & 135.2 & 123.5 & 11.90 & 11.32 & 0.759 \\
\hline February & 135.6 & 55.2 & 20.90 & 145.0 & 132.6 & 12.57 & 12.27 & 0.768 \\
\hline March & 178.3 & 73.5 & 23.20 & 185.4 & 170.2 & 15.91 & 15.53 & 0.760 \\
\hline April & 197.0 & 82.5 & 27.00 & 199.4 & 183.4 & 16.74 & 16.33 & 0.743 \\
\hline May & 229.1 & 91.5 & 30.80 & 227.9 & 210.0 & 18.70 & 18.23 & 0.725 \\
\hline June & 220.4 & 95.4 & 32.80 & 217.1 & 199.7 & 17.79 & 17.35 & 0.725 \\
\hline July & 209.0 & 107.6 & 34.30 & 206.8 & 189.8 & 16.95 & 16.54 & 0.725 \\
\hline August & 207.2 & 97.4 & 34.60 & 208.4 & 191.6 & 16.98 & 16.56 & 0.721 \\
\hline September & 192.7 & 77.1 & 32.20 & 198.0 & 182.3 & 16.22 & 15.81 & 0.724 \\
\hline October & 175.0 & 61.0 & 29.30 & 185.5 & 170.7 & 15.47 & 15.09 & 0.738 \\
\hline November & 134.1 & 48.3 & 25.50 & 146.7 & 133.8 & 12.36 & 12.08 & 0.747 \\
\hline December & 118.8 & 46.2 & 21.89 & 131.2 & 119.3 & 11.34 & 10.10 & 0.698 \\
\hline Year & 2121.0 & 884.1 & 27.72 & 2186.5 & 2007.0 & 182.96 & 177.21 & 0.735 \\
\hline
\end{tabular}

Legends: GlobHor Horizontal global irradiation $\quad$ GlobEff Effective Global, corr. for IAM and shadings DiffHor Horizontal diffuse irradiation EArray Effective energy at the output of the array

T Amb Ambient Temperature E_Grid Energy injected into grid GlobIncGlobal incident in coll. plane PR Performance Dubai SAE H

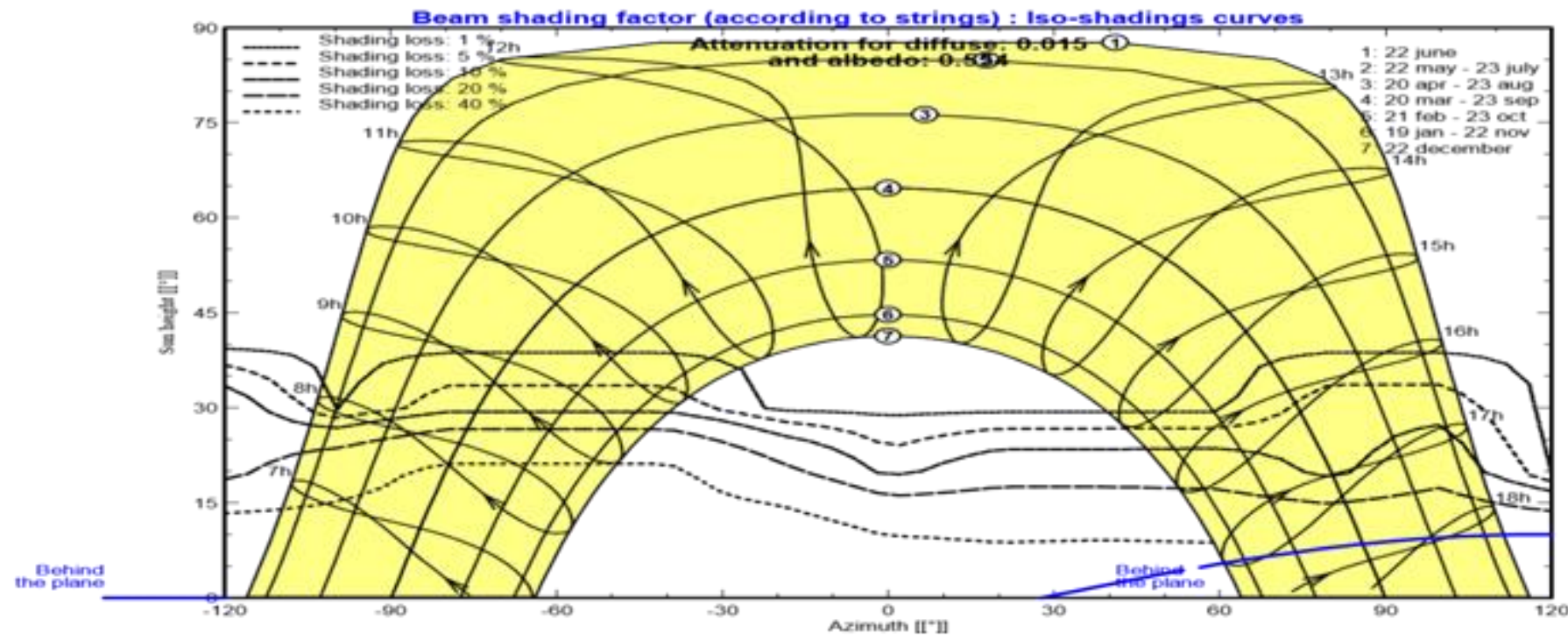

Fig. 6. Fig. 5. Path of the Sun over a year. 


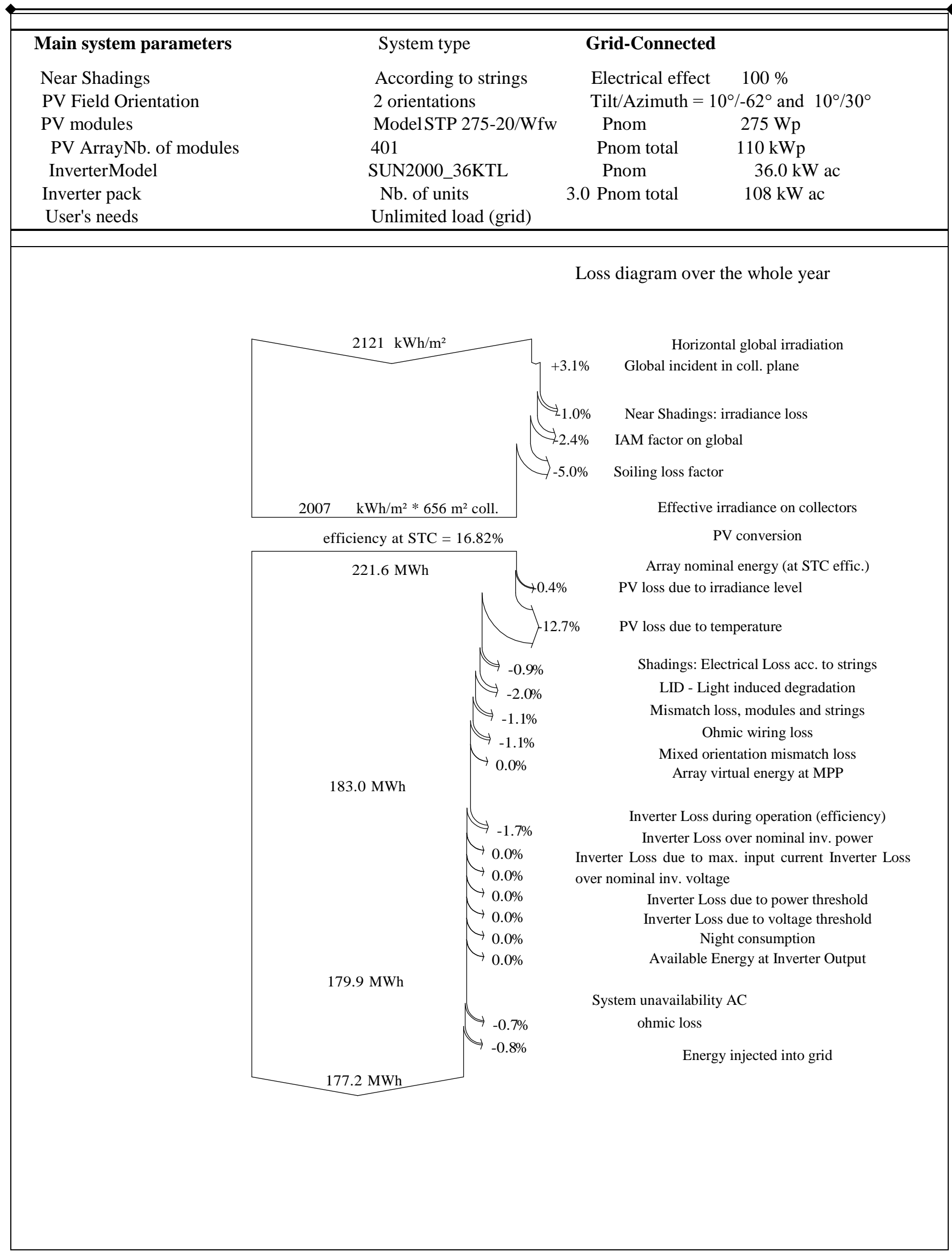

Fig. 7. Grid connected System : Loss diagram 
emissions. The equivalent $\mathrm{CO}_{2}$ emissions avoided by using the PV systems have been calculated based on the $\mathrm{CO}_{2}$ emission resulting from the conventional electricity generation in the UAE, which is about $938 \mathrm{~g} \mathrm{CO} 2$ eq $/ \mathrm{kWh}$ [8]. The $\mathrm{CO}_{2}$ emission from electricity generation in Western Europe is in the range $480-530 \mathrm{~g} \mathrm{CO}_{2 e q} / \mathrm{kWh}$ $[9,10]$. In addition, $671 \mathrm{~g} \mathrm{CO}$ eq $/ \mathrm{kWh}$ was reported for Hong Kong [11], $12 \mathrm{~g} \mathrm{CO}_{2 \mathrm{eq}} / \mathrm{kWh}$ for

Norway [10]. The difference in the amount of $\mathrm{CO}_{2}$ emissions between these countries is due to various mixes in their electricity generation where renewable energy sources are used alongside conventional ones.

\section{CONCLUSION}

A performance study of $108 \mathrm{KW}$ peak grids connected solar photovoltaic power plant installed at Dubai was evaluated on annual basis. The following conclusions are drawn from the study.

- Maximum total energy generation of $18.23 \mathrm{MW} \mathrm{h}$ was observed in the month of May and lowest total energy generation of $10.10 \mathrm{MWh}$ was observed in the month of December.Geographical location, the weather and other atmospheric conditions at the installation site. The direction your panels face, the temperature they reach, the angle of tilt they are on, the amount of dust and shading they encounter all affect the ability of the system to perform at its peak level.

The utilization of roof building will be increasing the amount of solar energy injected into grid and achieving dubai clean energy strategy 2050 goals, which we have launched to turn Dubai into a global hub for clean energy and green economy and become the lowest carbon footprint in the world by 2050 .

\section{REFERENCES}

[1] Angelo Baggini University of Bergamo."Handbook of Power Quality",

[2] State of Energy Report Dubai 2014 www.dcce.ae/energyreport.

[3] Central Electricity Regulatory Commission (2015) CERC, New Delhi.

[4] Gan CK, Tan PH, Khalid S (2013) System Performance Comparison Between Crystalline and Thin-Film Technologies under Different Installation Conditions. IEEE Conference on Clean Energy and Technology 362-367.

[5] Ahmed MM (2003) Design and Proper Sizing of Solar Energy Schemes for Electricity Production in Malaysia. National Power and Energy Conference (PECon) Proceedings 268-271.
[6] Singh VP, Ravindra B, Vijay V, Bhatt MS (2014) A comparative performance analysis of C-Si and A-Si PV based rooftop grid tied solar photovoltaic systems in Jodhpur. 3rd International Conference On Renewable Energy Research And Applications 250-255.

[7] D.V. Tugay, Yu.P. Kolontaevsky, S.V. Kotelevets, Ye.S. Savchuk "SOLAR POWER PLANT OPERATION MODELING IN SMART GRID ELECTRICITY SUPPLY SYSTEM “-

[8] Ismail H. Altas and Adel M. Sharaf."Solar Energy and PV Systems.

[9] Endo E, Kurokawa K (1994) Sizing Procedure For Photovoltaic Systems. IEEE 1:1196-1199.

[10] Zolkapli M, Al-Junid SAM, Othman Z, ManutA, MohdZulkifli MA (2013) HighEfficiency Dual-Axis Solar Tracking Developement using Arduino. International Conference on Technology, Informatics, Management, Engineering and Environment 23-26.

[11] M.M. A. Khan,M.Asif,E.Stach .Rooftop PV Potential in the Residential Sector of the Kingdom of Saudi Arabia

[12] Muhammed A. Ahmed, and Sidra A. Shaikh -Solar Radiation Studies for Dubai and Sharjah, UAE- 2013.

[13] Duffie JA, Beckman WA (2013) Solar Engineering of Thermal Processes (2nd edn). New York

[14] Sulaiman SA, Hussain HH, NikLeh NSH, Razali MSI (2011) Effects of Dust on the Performance of PV Panels. World Academy of Science, Engineering and Technology 5: 2028-2033

[15] Green MA (1982) Solar cells: operating principles, technology and system applications. Prentice-Hall, Inc., Englewood Cliffs, NJ, USA.

[16] Cambell M (2008) The Drivers of the Levelized Cost of Electricity for UtilityScale Photovoltaics. Sun Power.

[17] Solar Radiation Monitoring Laboratory, University of Oregon.

[18] Tyagi AP (1988) Solar Radiant Energy Over India. Indian Meteorological Department, India.

[19] Shongwe S, Hanif M (2015) Comparative Analysis of Different Single-Diode PV Modeling Methods. IEEE Journal of Photovoltaics 5: 938-946.

[20] Villalva MG, Gazoli JR, Filho ER (2009) Comprehensive Approach to Modeling and Simulation of Photovoltaic Arrays. IEEE Transactions On Power Electronics 24: 1198-1208.

[21] Developing renewable energy projects-A guide to achieving success in the Middle East- www.pwc.com/me -JAN.2016.

[22] Saudi Arabia needs to utilize the building sector for PV application to help achieve its $9.5 \mathrm{GW}$

[23] Renewable energy targets. The study examines the residential sector of Saudi Arabia for rooftop PV

[24] Muhammad Asif-Urban Scale Application of Solar PV to Improve Sustainability in the Building and the Energy Sectors of KSA2016.

[25] B. Sh.Kumar, K. Sudhakar.Performance evaluation of 10 MW grid connected solar photovoltaic Power plant in India.

[26] M.Al Ali,M.Emziane.Performance Analysis of Rooftop PV Systems in Abu Dhabi-2013

\title{
Оцінка працездатності сонячної фотоелектричної системи, підключеної до електромережі потужністю $108 \kappa \mathrm{BT}$
}

\author{
Haidar Gafar Abugoukh \\ O.M. Beketov National University of Urban Economy in Kharkov \\ Ukraine
}

Сонячна енергетика стала останнім десятиліттям найбільш швидко зростаючою технологією вироблення енергії в світі, головним чином завдяки широкомасштабному впровадженню цієї технології комунальними та приватним сектором. Підвищення рівня обізнаності щодо зміни клімату, енергетична безпека потребує сприяння зменшенню урядом витрат на 
сонячну енергію та появі нового та інноваційного бізнесу - одні з головних рушій для масштабного розвитку та використання сонячної енергії. Важливість сонячної енергії Сонячна енергія є важливою частиною життя і $є$ з початку часу. Все частіше людина вчиться використовувати цей важливий ресурс і використовувати його для заміни традиційних джерел енергії. Сонячна енергія важлива для природи: Сонячна енергія є важливою частиною майже кожного життєвого процесу, якщо ні, всіх життєвих процесів. Сонячна енергія важлива як чиста енергія: Оскільки сонячна енергія є повністю природною, вона вважається чистим джерелом енергії. Це не порушує навколишнє середовище і не створює загрози екосистемам, як це може призвести нафта та деякі інші джерела енергії. Він не викликає парникових газів, забруднення повітря чи води. Це дослідження має на меті розробити та оцінити підключені до мережі сонячні фотоелектричні системи на даху. Проект та техніко-економічне обгрунтування проекту сонячної фотоелектричної системи на даху проводяться за допомогою інструментів - PVsyst. Працездатність системи моделювали за допомогою програмного забезпечення PVsyst та аналізували результати. Аналіз результатів моделювання показує, що максимальне загальне вироблення енергії 18,23 МВт-год спостерігалось у травні місяці, а найнижча загальна генерація енергії - 10,10МВт-год - у грудні. Використання будівлі на даху буде збільшувати кількість сонячної енергії, що вводиться в електромережу. Використання споруди для даху буде збільшувати кількість сонячної енергії та досягати цілей стратегії Дубая з чистої енергетики Дубая на 2050 рік, яка має на меті забезпечити сім відсотків енергії Дубая за допомогою чистої енергії до 2020 року, 25 відсотків до 2030 року та 75 відсотків цент до 2050 року.

Ключові слова - сітка, фотоелектрична (PV); коефіцієнт продуктивності 